\title{
NAUCZYCIEL DLA NAUCZYCIELI I WYCHOWAWCÓW. MICHAŁ FRIEDLÄNDER JAKO POPULARYZATOR WIEDZY O WYCHOWANIU W LATACH MIĘDZYWOJENNYCH
}

\begin{abstract}
AвSTRAct. Michalska Iwonna, Nauczyciel dla nauczycieli i wychowawców. Michat Friedländer jako popularyzator wiedzy o wychowaniu w latach międzywojennych [A Teacher for Teachers and Educators. Michał Friedländer as a Promoter of Expertise in Education in the Interwar Period]. Studia Edukacyjne nr 48, 2018, Poznań 2018, pp. 133-149. Adam Mickiewicz University Press. ISSN 1233-6688. DOI: 10.14746/ se.2018.48.9

Michał Friedländer (1894-1942/1943?), a doctor of law by education, left his profession very quickly after his studies in Vienna. At the beginning, he conducted intensive educational project in Borysław and then, having moved to Krakow, became a teacher of German and induction to philosophy in the Private Co-Educational Gymnasium of the Jewish Society of Elementary and Secondary Schools [Żydowskie Towarzystwo Szkoły Ludowej i Średniej]. At the same time, he started cooperating with Polish and Jewish pedagogical and social magazines, where he published works dedicated mainly to the didactics of teaching modern languages and the education of children and teenagers. He was also the author of separate volumes and brochures dedicated to those issues.

He sometimes also wrote about co-education, reading of children and teenagers, past and modern school reformers, and schools opened abroad as a result of new tendencies in education. He published information on functioning of out-of-school education in various European countries and held radio lectures, organized by the Ministry of Education, on the main assumptions of "new pedagogy".

Although he did not create new theories, his greatest services consisted in propagating thoughts and solutions resulting from various "new education" tendencies. He was probably one of few people in those years who consistently introduced teachers and educators to foreign reformist pedagogical ideas.
\end{abstract}

Key words: Michał Friedländer, didactics of modern languages, pedagogical and psychological fundamentals of educating children and teenagers, Interwar Poland

W latach Drugiej Rzeczypospolitej w upowszechnianie wiedzy pedagogicznej angażowało się wielu nauczycieli szkół powszechnych i średnich. Podejmując najczęściej współpracę z redakcjami czasopism, dzielili się z czy- 
telnikami swoimi refleksjami nad zagadnieniami wychowawczymi, wynikającymi zwykle z codziennej praktyki oraz informowali o własnych doświadczeniach dydaktycznych. Różnili się oni wykształceniem - niektórzy mieli ukończone seminaria nauczycielskie lub pedagogia, inni studia uniwersyteckie, a bywało, że legitymowali się stopniem naukowym doktora. Pochodzili z dużych i mniejszych miast, jak Warszawa, Wilno, Poznań, Lublin, Równe, Siedlce, Ostrowiec, Inowrocław, Leszno, Brześć nad Bugiem oraz małych miejscowości - na przykład Oszmiany, Różyn, Szereszów, Druja, Koźmin, Oziaty, czy Chruszczyn. Część z nich publikowała sporadycznie, albo od czasu do czasu, część systematycznie zasilała swoimi tekstami łamy periodyków pedagogicznych. Teksty w nich zamieszczali między innymi: Józef Dziewiecki, Jan Moszczyk, Franciszek Rusin, Jan Woźniak, Jerzy Stopa, Bolesław Jakubowski, Stefan Kamiński, dr Józef Targowski, Józef Czarnecki, Włodzimierz Topoliński, Franciszek Uroczyński, Julian Szpunar Lidia Muchówna, Adam Cieślikowski, Helena Ryszkowska, Franciszek Strojnowski ${ }^{1}$ Nazwiska tych osób nie zostały zapamiętane i współcześnie nie wywołują żadnych znaczeniowych skojarzeń.

Do grupy nauczycieli, którzy pozostawili poważnych rozmiarów dorobek należał Michał Friedländer - postać również zapomniana i w dużym stopniu nieznana. Zapomniana, gdyż jedynie badacze przeszłości pedagogicznej okresu międzywojennego dokonując kwerend, z pewnością przy okazji, napotykali na jego artykuły zamieszczane głównie w periodykach. Nieznana, gdyż z jednej strony jego rozproszony dorobek pozostaje do tej pory w większości nierozpoznany, z drugiej - wiedza o kolejach jego życia, wykształceniu, kierunkach działalności zawodowej oraz pozazawodowej jest stosunkowo niewielka.

Warto w tym miejscu wspomnieć, że krótki biogram M. Friedländera sporządził dwukrotnie Jan Hulewicz. Pierwszy raz napisał o nim w 1949 roku i zamieścił w czwartym numerze "Przeglądu Historyczno-Oświatowego", który mimo że był przygotowany do druku, nigdy nie ukazał się na rynku księgarskim z uwagi na zamknięcie pisma z powodów ideowo-politycznych. Zachowało się kilka jego egzemplarzy w postaci tak zwanych zeszytów szczotkowych, z których jeden przechowywany jest w Bibliotece Uniwersytetu Warszawskiego. Powtórnie, po dokonaniu drobnych zmian, zamieścił go osiem lat później w „Polskim Słowniku Biograficznym”. Obydwa krótkie życiorysy zawierają jedynie podstawowe dane o tym pedagogu i stanowić mogą punkt wyjścia do dalszych poszukiwań biograficznych.

${ }^{1}$ Zob. np. roczniki czasopism pedagogicznych okresu międzywojennego: „Przyjaciel Szkoły”, „Praca Szkolna”, „Życie Szkolne”, "Szkoła Powszechna”, „Miesięcznik Pedagogiczny”, „Przegląd Pedagogiczny, ,"Gimnazjum”, ,"Polska Oświata Pozaszkolna”, , ,Szkoła”, , Ruch Pedagogiczny”, ,Polonista”, „Dzienniki Urzędowe Kuratoriów Okręgów Szkolnych”. 


\section{Od prawnika do nauczyciela i pedagoga}

Michał Friedländer urodził się w 1894 roku w Skolem, niedaleko Stryja, w żydowskiej rodzinie inteligenckiej. Po uzyskaniu w 1912 roku matury w polskim gimnazjum humanistycznym w Drohobyczu, rozpoczął studia prawnicze na Uniwersytecie $\mathrm{w}$ Wiedniu, które $\mathrm{z}$ przerwą spowodowaną służbą wojskową w armii austriackiej ukończył w roku 1918, a rok później obronił doktorat z prawa. Równolegle uczęszczał na wykłady z germanistyki i historii. Przez rok studiował w wiedeńskiej Akademii Eksportowej, później przemianowanej na Wyższą Szkołę Handlu Światowego. Następnie odbył praktykę w sądzie krajowym i prowadził badania historyczne w "Instytut für Kulturforschung". W latach 1921-1922 pełnił funkcję urzędnika prywatnego w Borysławiu. Od początku pobytu w tym mieście prowadził ożywioną działalność oświatową, polegającą na organizowaniu kursów dla dorosłych, publicznych wykładów i odczytów z literatury. Powołał również bibliotekę powszechną, sprawując nad nią mery toryczną opiekę. Dodatkowo uczył języka niemieckiego w borysławskim Prywatnym Gimnazjum Realnym². W tym okresie jego dotychczasowe zainteresowania związane $\mathrm{z}$ wyuczonym zawodem zaczęły schodzić na dalszy plan. Nie sposób powiedzieć, dlaczego tak się stało. Można jedynie snuć przypuszczenia, że podjęte w Wiedniu i nieukończone studia w zakresie germanistyki oraz historii rozbudziły $\mathrm{w}$ nim inne jeszcze zamiłowania, które z czasem stały się nowym drogowskazem, podpowiadającym zmianę perspektywy postrzegania własnej zawodowej przyszłości. Wskazuje na to chociażby fakt, że w 1923 roku na Uniwersytecie Jagiellońskim zdał egzamin dający mu uprawnienia do nauczania w szkołach średnich języka niemieckiego - jako przedmiotu głównego i historii - jako pobocznego. Po przeniesieniu się do Krakowa, od roku szkolnego 1929/1930 został nauczycielem w Prywatnym Gimnazjum Koedukacyjnym Żydowskiego Towarzystwa Szkoły Ludowej i Średniej, pracując w nim do roku 1939. W placówce tej nauczał języka niemieckiego i propedeutyki filozofii. Od 1935 roku wchodził w skład Komisji Wychowawczej, której zadaniem było sprawowanie jednolitej opieki pedagogicznej nad młodzieżą w gimnazjum, szkole powszechnej i szkole rzemiosł prowadzonych przez wspomniane Towarzystwo ${ }^{3}$.

Występował ponad to jako prelegent kursów instruktorskich z filologii nowożytnej, organizowanych przez Ministerstwo Wyznań Religijnych i Oświe-

\footnotetext{
2 J. Hulewicz, Friedländer Michat, Polski Słownik Biograficzny, t. 7, Kraków 1958, s. 139-140.

${ }^{3}$ Zob. np. IV Sprawozdanie kierownictwa Gimnazjum Koedukacyjnego Typu Humanistycznego i czteroklasowej Szkoły Powszechnej Żydowskiego Towarzystwa Szkoły Ludowej i Średniej w Krakowie za rok szk. 1931-32, Kraków 1932, s. 34; VII Sprawozdanie Dyrekcji Prywatnego Gimnazjum Koedukacyjnego, Szkoły Powszechnej i Męskiej Szkoły Rzemiost Żydowskiego Towarzystwa Szkoły Ludowej i Średniej w Krakowie za rok szk. 1934-35, Kraków 1935, s. 32, 56.
} 
cenia Publicznego w Warszawie, Lwowie i Równem, wygłaszając referaty na temat: „Konwersacja na trzech stopniach nauczania”, „Lektury na trzech stopniach nauczania" i "Nauka o kulturze" ${ }^{4}$. Brał także udział w organizowanych w ramach "Collegium wykładów naukowych” w Krakowie spotkaniach, podczas których zapoznawał słuchaczy z życiem i twórczością Johanna Wolfganga von Goethego ${ }^{5}$.

Wiadomo jedynie, o czym wspomniał Jan Hulewicz, że zginął w nieznanych okolicznościach, najprawdopodobniej w 1942 lub 1943 roku, w wyniku eksterminacyjnej polityki władz okupacyjnych ${ }^{6}$. Informację o jego śmierci podał również „Głos Nauczycielski” w 1945 roku w drukowanych na swych łamach listach ofiar członków Związku Nauczycielstwa Polskiego oraz zasłużonych działaczy społecznych, kulturalnych i oświatowych, którzy nie przeżyli drugiej wojny światowej

Niezależnie od wskazanych obszarów zaangażowania M. Friedländera, istotne miejsce $\mathrm{w}$ jego życiu zajmowała działalność związana z przygotowywaniem artykułów do polskich i żydowskich czasopism o profilu pedagogicznym i społecznym oraz wydawaniem osobnych tomików i broszur. I choć rozpoczął publikowanie swoich prac w połowie lat dwudziestych wieku XX, to na okres krakowski przypada jego największa aktywność pisarska. Trzeba podkreślić, że środowisko, w którym przebywał z racji zatrudnienia sprzyjało podejmowaniu tego typu wysiłków. Wielu z nim współpracujących nauczycieli - zwłaszcza dr Anna Brossowa, dr Juliusz Feldhorn, dr Benzion Katz, J.I. Kohn, Chaim Löw, Ozjasz Mahler i dr Samuel Stending - ogłaszało drukiem utwory o charakterze naukowym, popularnonaukowym i literackim. Dorobek M. Friedländera świadczy, że skupiał się w zasadzie na dwóch torach rozważań: neofilologicznym i pedagogiczno-psychologicznym, pragnąc przybliżyć nauczycielom nowoczesne tendencje w zakresie nauczania nowożytnych języków obcych, zwłaszcza języka niemieckiego, oraz propagować wśród wychowawców najnowszą europejską myśl pedagogiczną.

\section{Pomoc w skutecznym nauczaniu nowożytnych języków obcych}

Skupienie się M. Friedländera na nauczaniu języków obcych nie było sprawą przypadku. Jako nauczyciel języka niemieckiego osobiście uważał,

\footnotetext{
${ }^{4}$ H. N., Kurs metodyczny języków obcych we Lwowie, „Neofilolog” 1932, z. 2, s. 66-67.

${ }^{5}$ Kollegjum wykładów naukowych, „Naprzód” 1932, nr 34, s. 8.

${ }^{6}$ J. Hulewicz, Michat Friedländer (1894-1942/3?), "Przegląd Historyczno-Oświatowy” 1949, nr 4, s. 82-84 (zeszyt szczotkowy).

7 Ci którzy odeszli, „Głos Nauczycielski” 1945, nr 2, s. 66.
} 
że należy śledzić najnowsze zachodnie dokonania w tej dziedzinie. Zapoznając się z obcymi wydawnictwami, nie tylko poszerzał własną wiedzę, ale co istotne, dzielił się nią z czytelnikami - kolegami po fachu, pragnąc, aby pogłębiała ich dotychczasowy zasób wiadomości na temat językowego kształcenia, a zastosowana w praktyce szkolnej ułatwiała uczniom edukację. Jego piśmiennictwo, dotyczące omawianego zagadnienia miało zróżnicowany charakter. Jako znawca nie tylko języka niemieckiego, ale i angielskiego oraz francuskiego koncentrował się na literaturze drukowanej w tych językach. Współpracując z periodykiem "Neofilolog”, powołanym przez Polskie Towarzystwo Neofilologiczne, od początku powstania pisma drukował na jego łamach recenzje najnowszych zagranicznych książek i prezentował skróty artykułów z zagranicznych czasopism, opatrując je komentarzami. Wyjaśniał czytelnikom, dlaczego należy przeczytać je w oryginale i na jakie fragmenty szczególnie zwrócić uwagę. W nieco mniejszym stopniu zamieszczał również własne przemyślenia powstałe pod wpływem tych lektur, pokazując, w jakim kierunku powinna zmierzać edukacja języków nowożytnych.

Pozostając pod wpływem niemieckiej myśli dydaktycznej uważał, że nie można sprowadzać, jak to miało powszechnie miejsce, nauczania języka obcego tylko do przyswajania przez uczniów słownictwa i zagadnień gramatycznych, ale łączyć je należy z charakterem i duchem kultury narodu, który się nim posługuje. Przyczyny istniejącego stanu rzeczy upatrywał zarówno w zbyt ogólnikowym potraktowaniu tej kwestii w obowiązujących programach nauczania, jak i niepodejmowaniu żadnych kroków w kierunku przygotowania szkolnych neofilologów do szerszego spojrzenia na prowadzony przedmiot. Pisząc na ten temat, wyjaśniał: „Stwierdzić należy, że «nauka o kulturze» jest w szkole naszej jeszcze w cieniu, głównie dzięki brakowi wskazówek i fachowej dyskusji, której rezultaty stałyby się miarodajne dla praktyki" ${ }^{\prime}$. W obszernym szkicu zaproponował zakres tego obszaru nauczania w odniesieniu do języka niemieckiego, zachęcając nauczycieli polskich szkół średnich ogólnokształcących typu humanistycznego, aby przybliżali młodzieży: życie codzienne Niemiec (żywność, napoje, zwyczaje spożywania posiłków, urządzenie mieszkań, życie rodzinne, zabawy i zwyczaje świąteczne), geografię Niemiec i topografię ośrodków kulturalnych (usytuowanie na mapie krain i miast, typowe krajobrazy, dorobek cywilizacyjny), kulturę materialną Niemiec współczesnych (bogactwa naturalne, przemysł, handel, rolnictwo, komunikacja), historię Niemiec (najważniejsze wydarzenia od średniowiecza po czasy współczesne), ustrój i stosunki polityczne

${ }^{8}$ M. Friedländer, Zakres "Nauki o kulturze" w nauczaniu jezzyka niemieckiego, "Neofilolog" 1930, z. 3, s. 142. 
Niemiec (typ rządów, podział administracyjny, różnice polityczne między południem a północą państwa), a także niemiecką literaturę piękną i naukową, sztukę, muzykę, wielkich ludzi, stosunki kulturalne z innymi krajami kontynentu, a w szczególności z Polską. Nie ograniczył się jednak tylko do zarysowania programu "nauki o kulturze", ale precyzyjnie wskazywał czas wprowadzania poszczególnych treści z rozpisaniem na lata nauki oraz sugerował metody i środki dydaktyczne niezbędne do ich realizacji ${ }^{9}$.

Równolegle do podjętego wątku wprowadzania uczniów w kulturę narodów, których język poznawali, polecał germanistom zapoznawanie się z wybranymi dziełami autorów niemieckich piszących o własnym państwie oraz publikacjami ukazującymi się w Polsce o tym kraju w celu zdobywania i poszerzania wiedzy na temat „zachodnich sąsiadów” drogą samokształcenia. Proponowana przez niego literatura dawała nauczycielom wgląd w dzieje polityczne Niemiec, ważniejsze epoki kulturalne, rozwój budownictwa i techniki, tradycje i obyczaje oraz pozwalała zaznajomić się z wielkimi filozofami, pisarzami i poetami, współczesnym piśmiennictwem i trendami w sztuce ${ }^{10}$.

M. Friedländer reprezentował pogląd, że nowe cele i zadania stawiane przed neofilologami wymagały innego niż dotychczas podejścia do ich kształcenia językowego, które zresztą już wcześniej krytykowano albo za wydawanie dyplomów ludziom z niedostateczną znajomością języka przy jednoczesnym braku wyposażenia ich chociażby w teoretyczne instrumenty przydatne w procesie nauczania, albo za promowanie „naukowców” niezdatnych mentalnie do pracy z dziećmi i młodzieżą.

M. Friedländer traktując bardzo poważnie głosy o niewłaściwym przygotowaniu nauczycieli języków nowożytnych do zawodu, które płynęły z różnych ośrodków zagranicznych, zaznajamiał polskich czytelników z wysuniętą przez środowiska niemieckich językoznawców propozycją zreformowania studiów neofilologicznych w kierunku dostosowania ich do wymagań szkolnych. $\mathrm{Z}$ zadowoleniem komentował zapisy zamieszczone w od podstaw wypracowanym dla nich programie kształcenia, głoszące, że studium fachowe

9 Tamże, s. 143-155.

${ }^{10}$ M. Friedländer, Dr. W. Hofstaetter und Dr. F. Panze, Grundzüge der Deutschkunde 2Bände (I. Band, 259 Seiten 1925, II Band, 304 Seiten, 1929). B. G. Teubner, Leipzig Mk. 8+10; Dr. W. Hofstaetter, Deutschkunde - Ein Buch von deutscher Art und Kunst. Mit 42 Tafeln und 2 Karten. 226 Seiten, V. Aufl. B. G. Teubner, Leipzig 1929. Mk 5, „Neofilolog” 1930, z. 2, s. 101-102; tenże, Dr Walter Borkowsky, Die deutsche Romantic. („Führer zur deutschen Dichtung”. 5. Heft). Nakt. Ferd. Hirt, Breslau 1929, str. 182, Mk 4.50, „Neofilolog” 1930, z. 3, s. 185; tenże, Deutsche Literatur, Leipzig 1930, Mk 8,50, „Neofilolog” 1930, z. 4, s. 270-271; tenże, Margarete Roseno, Gedichte unserer Zeit. Weidmannsche Buchhandlung, Berlin, 1929, MK, 2,60, „Neofilolog” 1931, z. 3, s. 154; tenże, Goethe w świetle nowszych badań, „Neofilolog” 1932, z. 3, s. 157-161; M. Friedländer, J. Piprek, Pokłosie rocznicy Goethego w Polsce, „Neofilolog” 1932, z. 3, s. 135-142. 
na uniwersytecie jest kośćcem wykształcenia neofilologicznego, absolwent musi posiąść umiejętności językowe zweryfikowane stosownymi egzaminami, wzbogacone dodatkowo grupami przedmiotów, pogłębiających wiedzę o konkretnych narodach i ich kulturze, odbyć co najmniej trzymiesięczny „staż” językowy w obcym kraju oraz przejść studium pedagogiki dla zapoznania się z tajnikami wiedzy pedagogiczno-metodycznej niezbędnej przyszłemu wychowawcy ${ }^{11}$.

Jeszcze inny aspekt zainteresowania M. Friedländera zagadnieniami pedeutologicznymi pojawił się pod wpływem artykułu Elsy Köhler, która na łamach czasopisma „Die Neueren Sprachen” próbowała zarysować wzór nauczyciela-neofilologa. Na podstawie jej tekstu uświadamiał polskim kolegom, że nie wystarczy tylko wprawa w mówieniu literackim językiem obcym, ale również konieczna jest znajomość języka codziennego. Jego zdaniem, nabycie tej umiejętności wymagało, przynajmniej raz na kilka lat, wyjazdów zagranicznych. Przypominał, że nie można dobrze nauczać bez minimalnej znajomości gramatyki historycznej oraz gruntownego opanowania gramatyki opisowej. Podkreślał konieczność podejmowania systematycznego samokształcenia nad językiem, polegającego na ciągłym poszerzaniu słownictwa, podejmowania wysiłków na rzecz rozumienia kultury innego narodu i traktowania wyuczonego języka jako duchowej własności. Zgadzał się też z tezą, że obowiązkiem nauczycieli jest poznać uzdolnienia językowe uczniów i dostosować do nich odpowiednie metody i środki dydaktyczne. Za równie istotne uznawał pogodę ducha jaką powinni się charakteryzować, gdyż bez tej cechy nie sposób stworzyć w klasie twórczej atmosfery, najbardziej sprzyjającej nauce języka obcego. O dodatkowej roli, jaką wyznaczał osobom wprowadzającym młode pokolenie w świat "nieznanych słów", wspominał w końcowej części omawianego opracowania, pisząc:

Dążenie do tego ideału powinno znamionować nauczycielstwo dzisiejsze, powinno zwłaszcza odznaczać neofilologów, zajmujących wśród nauczycielstwa szczególne stanowisko: pośredników między kulturą własną a obcą, pionierów ogólnego zrozumienia i porozumienia narodów ${ }^{12}$.

W sprawach nauczania języków nowożytnych M. Friedländer był otwarty na wszelkie reformatorskie rozwiązania oferowane przez zagranicznych pedagogów. Tak było w przypadku przybliżania postulatów metodycznych Waltera Schönbrunna, w których domagał się szerszego zainteresowania

${ }^{11}$ M. Friedländer, Ku reformie wykształcenia neofilologicznego w Niemczech, „Neofilolog” 1930, z. 1, s. 33-36.

${ }_{12}$ M. Friedländer, Jakim powinien być neofilolog jako nauczyciel?, „Neofilolog” 1930, z. 2, s. 110. Zob. też: M. Friedländer, Nowy nauczyciel, „Ruch Pedagogiczny” 1926, nr 10, s. 295-299. 
szkołą pracy oraz przemiany szkoły nauczającej i podającej wiadomości w szkołę umożliwiającą przeżywanie wiedzy ${ }^{13}$, referowania toczących się dyskusji nad przewartościowaniem i doborem lektur szkolnych w nauczaniu języków nowożytnych ${ }^{14}$, czy zachęcania do zapoznawania się z najnowszymi podręcznikami z zakresu dydaktyki szczegółowej języków obcych, proponujących inne niż dotychczas podejścia do prowadzenia lekcji ${ }^{15}$. Wyjaśniał nauczycielom wartość merytoryczną i przydatność książek szkolnych do gramatyki niemieckiej funkcjonujących na rynku wydawniczym ${ }^{16}$. Dostrzegał ponadto zalety stosowania nowatorskich środków dydaktycznych, będących wynikiem rozwoju techniki w postaci radia, które oferowało swoim słuchaczom kursy i lekcje języków obcych. Wyrażał opinię, że ożywiają one nużącą naukę, a przede wszystkim kładą nacisk na prawidłową wymowę i akcentowanie słów oraz intonację wyrażeń ${ }^{17}$. Dzielił się także własnymi kilkuletnimi doświadczeniami z wprowadzenia na zajęciach z języka niemieckiego tak zwanych protokołów lekcyjnych, sporządzanych zawsze przez dwóch wskazanych przez wójta klasowego uczniów, które stanowiły zapis ich przebiegu. Odczytywane na kolejnym spotkaniu, pełniły rolę przypominającą i ułatwiającą powtórzenie zebranym „przerobionego" materiału ${ }^{18}$.

Jego szeroka wiedza dydaktyczna, własne przemyślenia i praktyka szkolna spowodowały, że w 1935 roku opublikował pierwszą część książki zatytułowanej Lektura obcojezzyczna w szkole średniej, która zapoczątkowała nową serię wydawniczą: „Metodyczna Biblioteka Neofilologiczna”. Znalazły się w niej częściowo treści już wcześniej ogłaszane w wydawnictwach periodycznych, wzbogacone jednak szeregiem nowych szczegółowych rozwiązań i wskazówek dydaktycznych. Z pewnością, pozycja ta okazała się niezwykle przydatna nauczycielom języków obcych, ponieważ zawarł w niej kompletny wykład na temat miejsca oryginalnych utworów w edukacji neofilologicznej, sposobów doboru tej literatury w nauce szkolnej, nowoczesnych metod

${ }^{13}$ M. Friedländer, Nowe tendencje w nauczaniu języków nowożytnych, „Neofilolog” 1930, z. 3, s. 195-196.

${ }^{14}$ M. Friedländer, Walka o lekturę dla młodzieży, „Neofilolog” 1931, nr 3, s. 155-157; tenże, Sens nauczania języków obcych w szkole. Wychowanie państwowe a języki obce. Przyczynek do zagadnienia doboru lektury, „Neofilolog” 1931, z. 4-5, s. 221-224; tenże, Lektura obcojęzyczna w wydaniach szkolnych, "Neofilolog” 1935, z. 4, s. 237-241.

${ }_{15}$ M. Friedländer, Adolf Bohlen, Neusprachlicher, Leipzig, 1930, Mk 8; P. Hartig u. H.Strohmeyer, Moderner neusprachlicher Unterricht. Pläne Beispiele Und Vorschläge für Praxis, Braunschweig 1930, „Neofilolog” 1931, z. 1, s. 41-42.

${ }_{16}$ M. Friedländer, Język i gramatyka niemiecka w szkole, „Neofilolog” 1931, z. 4-5, s. 209-212.

${ }_{17}$ M. Friedländer, Radio jako środek nauczania języków, „Neofilolog” 1930, z. 2, s. 111-113.

${ }_{18}$ M. Friedländer, Protokoły lekcyjne jako środek metodyczny w nauczaniu języków obcych, „Neofilolog" 1935, z. 5, s. 246-249. 
i środków dydaktycznych, możliwości opracowywania tekstów oraz samodzielnej pracy ucznia nad lekturą.

Warto w tym miejscu wyjaśnić, że u podstaw wspomnianego wyżej opracowania legło przeświadczenie M. Friedländera o istotnej roli literatury dodatkowej w kształceniu językowym młodzieży. Nie będąc przeciwnikiem podręczników, uważał je jednak za twory sztuczne wynikające z wcześniej przyjętych założeń, stworzone i ułożone wedle wytyczonych zasad metodycznych. Dużo wyżej cenił jednak utwory oryginalne, w których słownictwo i zjawiska językowe występują w sposób swobodny i podporządkowane są jedynie twórczej myśli. Wyrażał pogląd, że w przeciwieństwie do książki szkolnej, której teksty służyć mają ćwiczeniom językowym, celom historyczno-literackim, czy kulturoznawczym, lektury wzbudzają refleksję i poruszają uczucia. Stąd, zachęcał nauczycieli, aby po pierwszych dwóch latach nauki języka, kiedy to ze względów metodycznych podręcznik odgrywa największe znaczenie, w kolejnych latach uzupełniać kształcenie dostosowanymi do wieku uczniów lekturami, zaś w liceum utwory oryginalne uczynić ośrodkiem całego nauczania. Widział też konieczność wykorzystywania podczas lekcji zagranicznych czasopism ${ }^{19}$.

W pozytywnej recenzji tego wydawnictwa Herman Sternbach pisał:

Praca Friedländera będzie dla neofilologa, a w szczególności zaś dla germanisty, miłym vademecum. Porusza bowiem wszystkie kwestie, jakie wiążą się z nauczaniem języka obcego w szkole średniej nowego ustroju (...). Będzie więc ta praca dobrym poradnikiem i dla „starego" germanisty, obytego czy zżytego z tą lub ową metodą, przede wszystkim zaś dla młodego nauczyciela, który jeszcze metodycznego doświadczenia nie posiada na tyle, by móc osiągać żądane i pożądane wyniki ${ }^{20}$.

Mimo że M. Friedländer poinformował czytelników o przygotowywaniu drugiej części książki, w której przewidywał zamieścić instrukcje postępowania dla nauczycieli, ułatwiające pracę dydaktyczną z różnymi gatunkami literackimi niemieckich lektur, bogato uzupełnione przykładowymi konspektami lekcji, tom taki nie ukazał się na rynku księgarskim.

Konsekwencją zajmowanego przez M. Friedländera stanowiska o konieczności wprowadzania do edukacji językowej oryginalnych dzieł stało się opracowanie przez niego i wydanie z myślą o młodzieży szkolnej utworów

${ }^{19}$ M. Friedländer, Lektura obcojęzyczna w szkole średniej. Szkic metodyczny, cz. I. Rozważania ogólne, Kraków 1935, s. 1-4; tenże, Gazeta w nauczaniu szkolnym, „Ruch Pedagogiczny” 1928, nr 2, s. 50 .

${ }^{20}$ H. Sternbach, Michat Friedländer:Lektura obcojęzyczna w szkole średniej. Szkic metodyczny. Część I. Rozważania ogólne. Metodyczna Biblioteka Neofilologiczna. Nr 1. Skład główny: Księgarnia Gebethner i Wolff. Kraków 1935, „Neofilolog” 1935, nr 4, s. 258. 
dramaturga i poety Friedricha Hebbla ${ }^{21}$, nowel Theodora Storma ${ }^{22}$, wyboru $\mathrm{z}$ „Fausta” Goethego ${ }^{23}$ oraz czytanek niemieckich ${ }^{24}$.

\section{Dostarczanie wiedzy o wychowaniu i jego uwarunkowaniach}

Odrębną problematykę, do której Michał Friedländer przywiązywał wiele uwagi stanowiły zagadnienia typowo pedagogiczne. Na jego dorobek w tym zakresie składają się liczne, zwykle wielostronicowe, artykuły, dzielone na części i zamieszczane w kilku kolejnych numerach periodyków. Zdarzało się, że niektóre ukazywały się również w postaci oddzielnych broszur. Dominowała w nich głównie problematyka dotycząca środowisk wychowawczych oraz rozwoju dzieci i młodzieży. Przygotowywane były na podstawie prac głównie niemieckich, angielskich i amerykańskich autorów.

Podstawą prezentowanych przez niego poglądów stanowiło przekonanie o ważnej roli wrodzonych dyspozycji w wychowaniu człowieka i jeszcze ważniejszej - czynników zewnętrznych. Dlatego, koncentrując się przede wszystkim na tych drugich, skupiał uwagę czytelników na osobotwórczym znaczeniu środowiska przyrodzonego, kulturalnego, personalnego i gospodarczego. Wyjaśniał, że wszystkie wywierają wpływ na jednostkę i ogniskują się $\mathrm{w}$ różnych proporcjach $\mathrm{w}$ środowisku domowym (stan majątkowy, położenie i wyposażenie mieszkania, odżywianie, poziom kultury rodziców, atmosfera życia rodzinnego), szkolnym (budynek, jego stan techniczny i estetyka wnętrz, osobowość nauczyciela, zbiorowość klasowa) oraz społecznym (różnorodne wzory zachowań), warunkując jednocześnie jej „wzrost” 25 .

$\mathrm{W}$ obszernych rozprawach rozwijał reprezentowany przez siebie punkt widzenia na wychowanie, dowodząc o bezwzględnej potrzebie uspołeczniania dziecka od najmłodszych lat. Przestrzegał, aby procesu tego nie odkładać na czas późniejszy. Sądził, iż do trzeciego roku życia powinno ono przebywać w otoczeniu rodziny, gdzie panuje intymniejsza, przytulniejsza i „łatwiejsza” atmosfera niż $w$ innych środowiskach. Uczy się ono wtedy drogą naśladowania rodziców i starszego rodzeństwa „wchodzić” w sferę odczuć, myśli i dążeń najbliższego środowiska. Wiek od 3 do 7 lat postrzegał jako okres

${ }^{21}$ F.Ch. Hebbel, Agnes Bernauer: ein deutsches Trauerspiel in 5 Akten, wydał oraz wstępem, posłowiem i przypisami zaopatrzył M. Friedländer, Lwów-Warszawa 1933.

${ }^{22}$ T. Storm, Immensee, wstępem i przypisami opatrzył Michał Friedländer, Lwów-Warszawa 1935.

${ }^{23}$ J.W. Goethe, Faust, przypisami opatrzył M. Friedländer, Lwów 1938.

${ }^{24}$ Münchhausens Reisen Und Abenteuer, opracował M. Friedländer, Kraków 1939.

${ }^{25}$ M. Friedländer, Znaczenie środowiska w wychowaniu, "Ruch Pedagogiczny” 1928, nr 9, s. $257-268$ i nr 10 , s. 298-302. 
przebywania w domu i przedszkolu. Wejście w otoczenie społeczności dziecięcej dawało szansę na nawiązywanie nowych kontaktów społecznych, powolne nabywanie umiejętności liczenia się z potrzebami kolegów, wyzwalanie uczuć koleżeństwa i przyjaźni oraz ofiarności na rzecz innych. Twierdził, że tylko postępowanie zgodne z tym scenariuszem spowoduje, iż wstąpienie $\mathrm{w}$ mury szkolne pozwoli na kontynuowanie, a nie dopiero rozpoczynanie realizacji idei wychowania społecznego ${ }^{26}$.

M. Friedländer dowodził również, że zabawy mające potężny wpływ na wszechstronny rozwój najmłodszych, mogą skutecznie przyczyniać się do socjalizacji dzieci. Z tego powodu dokładnie omawiał teorie, cechy i rodzaje zabaw, psychologiczne, estetyczne i higieniczne kryteria doboru zabawek oraz walory wychowawcze zabaw. Domagał się od społeczeństwa - rodziców, wychowawców, nauczycieli, a nawet władz lokalnych pełnego zrozumienia dla tej formy aktywności dzieckaa ${ }^{27}$.

Przekonywał również rodziców, że to oni powołani są w pierwszej kolejności do kształtowania osobowości dziecka, że jego rozwój powinni traktować jako stopniowe wrastanie w świat ludzi dorosłych, że przebywanie w rodzinie wpływa korzystnie na sferę emocjonalną potomstwa, że obowiązki wychowawcze wobec dziecka ma zarówno matka, jak i ojciec, a wreszcie - że do rodzicielstwa należy być odpowiednio przygotowanym ${ }^{28}$. Aby ułatwić im realizowanie wychowawczych zadań, powołując się na wyniki badań psychologii rozwojowej, pokazywał, jak ewoluuje stosunek dzieci do dorosłych w poszczególnych fazach rozwojowych - od urodzenia do wieku dojrzewania. Tę wiedzę uznał za podstawową wskazówkę, która powinna wyznaczać kierunek wszelkim oddziaływaniom rodziców. Będąc zdecydowanym przeciwnikiem postępowania autorytatywnego wobec dzieci i młodego pokolenia, charakteryzującego się rygorem, nakazami, zakazami, strachem i karami, postulował przyjęcie odmiennej perspektywy wychowawczej, która podpowiadała dorosłym wspieranie rozwoju indywidualnego dziecka i wymagała od nich działań opartych na prawdzie, swobodzie i szacunku wobec wychowanków ${ }^{29}$.

Równie dużo miejsca poświęcił M. Friedländer pokoleniu stojącemu u progu dorosłości. Zaznajamiał czytelników ze zmianami zachodzącymi w umysłowości i życiu uczuciowym dojrzewającej młodzieży oraz pojawia-

${ }^{26}$ M. Friedländer, Uspołecznianie się dziecka w wieku przedszkolnym, „Życie Dziecka” 1933, nr 7, s. $182-197$ i nr 8 , s. 209-222.

${ }^{27}$ M. Friedländer, Dziecko i zabawa, „Przegląd Społeczny” 1930, nr V, s. 172-180; nr VI, s. 205-209; nr VII, s. 244-253.

${ }^{28}$ M. Friedländer, Rodzice a wychowanie, „Przegląd Społeczny” 1929, nr III, s. 89-93.

${ }^{29}$ M. Friedländer, Dzieci i dorośli, „Przegląd Społeczny” 1931, nr VIII, s. 281-291; nr IX, s. 327-332; nr X, s. 364-371. 
niem się u niej zainteresowań erotyką i seksualnością. Wprowadzał w tajniki duchowego świata młodych dziewcząt, ich swoistych cech i potrzeb, takich jak posiadanie instynktu, intuicji, głębokiej uczuciowości, zmienności nastrojów, pragnienia bycia z kimś, poszukiwania autorytetu. Wskazując na różnorodność osobowości młodzieży żeńskiej, przyjął zaproponowaną przez Elzę Croner klasyfikację, która wyróżniała wśród nich typy macierzyńskie, erotyczne, romantyczne, trzeźwe i intelektualne. Kilkukrotnie podnosił problem wychowania płciowego, dążąc do przekazania nauczycielom i wychowawcom konkretnej wiedzy na temat fizjologii zjawiska fizycznego dojrzewania młodzieży, problemów występujących w tym okresie, możliwości sublimacji popędu płciowego, dając jednoznacznie do zrozumienia, że uświadamianie seksualne i związane z nim kwestie higieniczne i społeczno-etyczne ze wszech miar powinny należeć do obowiązków szkoły. Zapoznawał też z przejawami buntu młodzieży amerykańskiej przeciwko światopoglądowi, tradycji, zwyczajom, moralności starszego pokolenia, wyrażającego się w głoszeniu własnych poglądów i zapowiedzi tworzenia niepraktykowanych dotychczas form życia ${ }^{30}$.

Znając trudne warunki domowe, w jakich przyszło funkcjonować sporej części polskiej młodzieży i będąc świadomym licznych zagrożeń, które niosło ze sobą życie młodego pokolenia w środowiskach wielkomiejskich, apelował do nauczycielstwa, władz państwowych i lokalnych o objęcie tej grupy wiekowej stosowną opieką społeczną. Uważał, że pomoc powinna zmierzać w trzech kierunkach - materialnym, duchowym i moralnym. Dla jednych - pozostających w skrajnej nędzy - widział potrzebę zabezpieczenia lokali $\mathrm{w}$ postaci powoływania sieci świetlic, w których mogliby spędzać czas po zajęciach szkolnych, dostarczania żywności, odzieży i organizowania profilaktyki zdrowotnej, dla innych - zapewnienia dalszego kształcenia po ukończeniu siedmioletniej obowiązkowej nauki na kursach dla dorosłych, uniwersytetach ludowych, szkołach wieczorowych, bibliotekach, czytelniach na wzór oświaty pozaszkolnej organizowanej w wielu europejskich krajach, dla jeszcze innych - ze środowisk zaniedbanych i niewydolnych wychowawczo, dla których ulica stanowiła miejsce codziennej egzystencji - otwieranie specjalnych ognisk proponujących wartościowe sposoby spędzania czasu wolnego ${ }^{31}$.

${ }^{30}$ M. Friedländer, Zmiany duchowe młodzieży w wieku przełomowym, "Przegląd Społeczny" 1929, nr I, s. 3-12 i nr II, s. 49-59; tenże, Życie duchowe młodzieży żeńskiej, „Ruch Pedagogiczny” 1925, nr 9-10, s. 300-305; tenże, Zagadnienia ptciowe w wychowaniu młodzieży, "Przegląd Społeczny" 1929, nr VI, s. 216-226; nr VII, s. 244-253; nr VIII, s. 293-302; nr IX, s. 329-331, nr X, s. 373-384; tenże, Szkoła wobec zagadnień wychowania ptciowego, „Ruch Pedagogiczny” 1930, nr 3, s. 112-122; tenże, Rewolucja młodzieży wspótczesnej, „,Ruch Pedagogiczny” 1930, nr 1, s. 4-7.

${ }^{31}$ M. Friedländer, Zadania opieki społecznej nad młodzieża, "Przegląd Społeczny" 1928, nr IX, s. 9-18; tenże, Młodzież w środowisku wielkomiejskim, „Życie Dziecka” 1935, n1, s. 1-7; tenże, Oświata pozaszkolna w Niemczech, „Polska Oświata Pozaszkolna” 1931, nr 3, s. 145-154. 
Inny jeszcze nurt rozważań M. Friedländera dotyczył przybliżania nauczycielom najnowszej amerykańskiej, angielskiej i niemieckiej myśli pedagogicznej oraz przekonywania do rodzących się w Europie tendencji do szkolnego wychowywania uczniów w duchu pokoju. Zaznajamiał równocześnie z konkretnymi rozwiązaniami edukacyjnymi, które zrywały więzy z praktyką tradycyjnego kształcenia. Ukazywał między innymi funkcjonowanie szkoły pracy produktywnej Paula Oestreicha, farmy szkolnej Scharfenber pod Berlinem, czy modnej wśród pedagogów zachodnich szkoły Rabindranatha Tagorego w Szantiniketan ${ }^{32}$.

W popularyzowanie praktyki „nowego wychowania” wpisują się dodatkowo artykuły podnoszące problem czytelnictwa dzieci i młodzieży, które - jego zdaniem - przyczynia się nie tylko do zdobywania i pogłębiania wiedzy, ale dostarcza różnego rodzaju przeżyć, wyrabia samodzielność i przygotowuje do samokształcenia. Studiując literaturę obcą na ten temat, dzielił się wynikami z przeprowadzanych badań dotyczących obcowania młodego pokolenia $\mathrm{z}$ książką, poglądami na temat roli literatury w wychowaniu, a także sposobami rozbudzania zainteresowań lekturami i zasadami ich doboru ${ }^{33}$.

Do sporadycznie podejmowanych przez M. Friedländera zagadnień należał, stosunkowo często goszczący w wielu publikacjach okresu międzywojennego, problem koedukacji. Przyjmując, że oznacza ona wspólne wychowanie dziewcząt i chłopców, gorąco opowiadał się za uwzględnianiem jej w szkolnictwie zarówno powszechnym, jak i średnim. Wśród walorów wymieniał uczenie przez płeć żeńską ogłady towarzyskiej i manier swoich kolegów, poznawanie wzajemnych upodobań i zdolności, rozumienia czym jest koleżeństwo, przeciwdziałanie flirtom. Z kolei, z pewnym zatroskaniem odnosił się do koinstrukcji, czyli wspólnego nauczania obydwu płci. Nie negując możliwości wspólnego ich kształcenia, dostrzegał różnice w zainteresowaniach

${ }^{32}$ M. Friedländer, Psychologia a pedagogika w Stanach Zjednoczonych, "Miesięcznik Pedagogiczny” 1929, nr 6-7, s. 161-164; tenże, Myśl pedagogiczna za granica, "Miesięcznik Pedagogiczny"1928, nr 5, s. 137-141; 1928, nr 8-9, s. 200-204; 1929, nr 10, s. 230-236; tenże, Centralny Instytut Wychowania i Nauczania w Niemczech, „Miesięcznik Pedagogiczny” 1928, nr 6-7, s. 172-175; tenże, O wymianę myśli pedagogicznej z zagranica, "Przegląd Pedagogiczny” 1926, nr 26, s. 706; tenże, Nowe szkolnictwo w Niemczech, "Przegląd Pedagogiczny” 1926, nr 33, s. 868; tenże, Wychowanie, szkoła i pokój, „Ruch Pedagogiczny” 1927, nr 8, s. 238-242 i nr 9, s. 275-278; tenże, Romain Rolland a wychowanie, „Ruch Pedagogiczny” 1926, nr 8, s. 225-228; tenże, Oestreicha idea szkoty produktywnej, „Ruch Pedagogiczny" 1927, nr 2, s. 42-44; tenże, Farma szkolna jako typ nowej szkoty, "Ruch Pedagogiczny" 1929, nr 1, s. 15-20; tenże, Szkota Rabindranatha Tagorego w Szantiniketan, „Ruch Pedagogiczny" 1926, nr 3, s. 80-82.

${ }_{33}$ M. Friedländer, O aktualna lekturę szkolna, „Przegląd Pedagogiczny” 1927, nr 29, s. 683; tenże, Problemy czytelnictwa dzieci i młodzieży zagranica, "Miesięcznik Pedagogiczny” 1930, nr 1, s. 1-11; tenże, Szkoła i młodzież wobec literatury, "Oświata i Wychowanie” 1930, nr 1, s. 74-76; tenże, Dziecko a książka, "Oświata i Wychowanie”" 1930, nr 1, s. 76-79. 
oraz intelektualnych predyspozycjach dziewcząt i chłopców, podpowiadając, że wymaga ono przeprowadzenia głębokich zmian w układzie programu nauczania w szkolnictwie koedukacyjnym oraz bezwzględnego odwoływania się do metody indywidualnego podejścia do uczniów ${ }^{34}$.

M. Friedländer wchodził również w rolę sprawozdawcy radiowych wykładów z pedagogiki nadawanych na warszawskich falach eteru, których transmisje, dzięki inicjatywie Ministerstwa WRiOP, rozpoczęto w styczniu 1927 roku. Jego teksty z jednej strony miały na celu informowanie nauczycielstwa o pojawieniu się nowej formy kierowanego do nich przekazu i zachęcanie do korzystania z tej możliwości samokształcenia, z drugiej - przekazywanie $\mathrm{w}$ postaci skróconej wygłaszanych prelekcji przeznaczonych głównie dla osób nieposiadających dostępu do radioodbiorników. Wysoko oceniając poziom naukowy pierwszych audycji, w których wystąpili: Władysław Radwan, Bogdan Nawroczyński, Tadeusz Łopuszański, Maria Grzegorzewska, Tadeusz Kupczyński, Józefa Joteyko, Zofia Żukiewiczowa, Jan Hellman, Władysław Przanowski i Sławomir Czerwiński, zwrócił uwagę na niedociągnięcia przekazu językowego zapraszanych przez rozgłośnię gości ${ }^{35}$. Wyjaśniał:

F o r m a tylko szwankuje niekiedy: zauważyć bowiem się daje u niektórych prelegentów nużąca jednostajność dykcji, połykanie końcówek lub nawet całych słów na końcu zdań oraz skomplikowana ich budowa. Mikrofon wymaga modulacji głosu, bardzo wyraźnego wymawiania słów i jasnego stylu zwięzłych zdań. Prelegenci, piszący swe prelekcje do odczytania ich przed mikrofonem, muszą zważać na radiofoniczność wykładów ${ }^{36}$.

Podsumowując, należy stwierdzić, że na dorobek Michała Friedländera w zakresie dydaktyki nauczania języków nowożytnych i wychowania dzieci oraz młodzieży składa się kilkadziesiąt publikacji nie tylko zamieszczanych we wspomnianym wcześniej "Neofilologu”, ale także w takich czasopismach, jak „Ruch Pedagogiczny”, „Życie Dziecka”, „Przegląd Pedagogiczny", ,"Przegląd Społeczny”, ,Miesięcznik Pedagogiczny”, , Oświata i Wychowanie", „Polska Oświata Pozaszkolna”. I choć nie tworzył nowych teorii, to jego największą zasługą było propagowanie treści i rozwiązań wynikających z różnorodnych nurtów "nowego wychowania”. Należał do niewielu osób w tamtych latach, która z wielką konsekwencją w prowadzała systematycznie nauczycieli i wychowawców w najnowszą zagraniczną myśl pedagogiczną.

${ }^{34}$ M. Friedländer, Koedukacja i koinstrukcja, „Ruch Pedagogiczny” 1926, nr 5, s. 151-156 i nr 6, s. 171-179.

${ }^{35}$ M. Friedländer, Pedagogika w Radio, „Ruch Pedagogiczny” 1927, nr 3, s. 82-84; tenże, Wykłady radiowe $z$ dziedziny pedagogiki Min. W. R. i O. P, „Ruch Pedagogiczny” 1927, nr 5, s. 151-152.

${ }^{36}$ M. Friedländer, Pedagogika, s. 84. 
Stąd, bardziej można nazwać go sprawozdawcą niż prezenterem własnych poglądów. W tym zakresie można całkowicie zgodzić się z Janem Hulewiczem, który o nim pisał:

Niezmiernie chłonny i wrażliwy, choć nie był umysłem twórczym, położył poważne zasługi na polu recepcji i rozpowszechniania obcej reformistycznej myśli pedagogicznej lat 1918-1939. Był jednym z najżarliwszych jej popularyzatorów ${ }^{37}$.

\section{BIBLIOGRAFIA}

Ci którzy odeszli, „Głos Nauczycielski” 1945, nr 2.

IV Sprawozdanie kierownictwa Gimnazjum Koedukacyjnego Typu Humanistycznego i czteroklasowej Szkoty Powszechnej Żydowskiego Towarzystwa Szkoty Ludowej i Średniej w Krakowie za rok szk. 1931-32, Kraków 1932.

Hebbel F.Ch., Agnes Bernauer: ein deutsches Trauerspiel in 5 Akten, wydał oraz wstępem, posłowiem i przypisami zaopatrzył M. Friedländer, Lwów - Warszawa 1933.

Friedländer M., Adolf Bohlen, Neusprachlicher, Leipzig, 1930, Mk 8; P. Hartig u. H.Strohmeyer, Moderner neusprachlicher Unterricht. Pläne Beispiele Und Vorschläge für Praxis, Braunschweig 1930, „Neofilolog” 1931, z. 1.

Friedländer M., Centralny Instytut Wychowania i Nauczania w Niemczech, „Miesięcznik Pedagogiczny" 1928, nr 6-7.

Friedländer M., Deutsche Literatur, Leipzig 1930, Mk 8,50, „Neofilolog” 1930, z. 4.

Friedländer M., Dr Walter Borkowsky, Die deutsche Romantic. („Führer zur deutschen Dichtung”. 5. Heft). Nakt. Ferd. Hirt, Breslau 1929, str. 182, Mk 4.50, „Neofilolog” 1930, z. 3.

Friedländer M., Dr. W. Hofstaetter und Dr. F. Panze, Grundzüge der Deutschkunde 2Bände (I. Band, 259 Seiten 1925, II Band, 304 Seiten, 1929). B. G. Teubner, Leipzig Mk. 8+10; Dr. W. Hofstaetter, Deutschkunde - Ein Buch von deutscher Art und Kunst. Mit 42 Tafeln und 2 Karten. 226 Seiten, V. Aufl. B. G. Teubner, Leipzig 1929. Mk 5, „Neofilolog” 1930, z. 2.

Friedländer M., Dziecko a ksiażka, „Oświata i Wychowanie” 1930, nr 1.

Friedländer M., Dziecko i zabawa, „Przegląd Społeczny” 1930, nr V, VI, VII.

Friedländer M., Dzieci i dorośli, „Przegląd Społeczny” 1931, nr VIII, IX, X.

Friedländer M., Farma szkolna jako typ nowej szkoty, ",Ruch Pedagogiczny” 1929, nr 1.

Friedländer M., Gazeta w nauczaniu szkolnym, „Ruch Pedagogiczny” 1928, nr 2.

Friedländer M., Goethe w świetle nowszych badań, „Neofilolog” 1932, z. 3.

Friedländer M., Jakim powinien być neofilolog jako nauczyciel? "Neofilolog” 1930, z. 2.

Friedländer M., Jezzyk i gramatyka niemiecka w szkole, „Neofilolog” 1931, z. 4-5.

Friedländer M., Koedukacja i koinstrukcja, „Ruch Pedagogiczny” 1926, nr 5 i nr 6.

Friedländer M., Ku reformie wyksztatcenia neofilologicznego w Niemczech, „Neofilolog” 1930, z. 1 .

Friedländer M., Lektura obcojęzyczna w szkole średniej. Szkic metodyczny, cz. I. Rozważania ogólne, Kraków 1935.

Friedländer M., Lektura obcojęzyczna w wydaniach szkolnych, „Neofilolog” 1935, z. 4.

Friedländer M., Margarete Roseno, Gedichte unserer Zeit. Weidmannsche Buchhandlung, Berlin, 1929, MK, 2,60, „Neofilolog” 1931, z. 3.

${ }^{37}$ J. Hulewicz, Michat Friedländer, s. 84. 
Friedländer M., Młodzież w środowisku wielkomiejskim, „Życie Dziecka” 1935, n1.

Friedländer M., Myśl pedagogiczna za granica, „Miesięcznik Pedagogiczny”1928, nr 5, 1928, nr 8-9, 1929, nr 10.

Friedländer M., Nowe szkolnictwo w Niemczech, „Przegląd Pedagogiczny” 1926, nr 33.

Friedländer M., Nowe tendencje w nauczaniu języków nowożytnych, "Neofilolog” 1930, z. 3.

Friedländer M., Nowy nauczyciel, „Ruch Pedagogiczny” 1926, nr 10.

Friedländer M., O aktualną lekturę szkolna, „Przegląd Pedagogiczny” 1927, nr 29.

Friedländer M., Oestreicha idea szkoty produktywnej, „Ruch Pedagogiczny” 1927, nr 2.

Friedländer M., Oświata pozaszkolna w Niemczech, „Polska Oświata Pozaszkolna” 1931, nr 3.

Friedländer M., O wymianę myśli pedagogicznej z za granica, „Przegląd Pedagogiczny” 1926, nr 26.

Friedländer M., Pedagogika w Radio, „Ruch Pedagogiczny” 1927, nr 3.

Friedländer M., J. Piprek, Pokłosie rocznicy Goethego w Polsce, „Neofilolog” 1932, z. 3.

Friedländer M., Problemy czytelnictwa dzieci i młodzieży za granica, „Miesięcznik Pedagogiczny" 1930, nr 1.

Friedländer M., Protokoły lekcyjne jako środek metodyczny w nauczaniu języków obcych, „Neofilolog" 1935, z. 5.

Friedländer M., Psychologia a pedagogika w Stanach Zjednoczonych, „Miesięcznik Pedagogiczny" 1929, nr 6-7.

Friedländer M., Radio jako środek nauczania języków, „Neofilolog” 1930, z. 2.

Friedländer M., Rewolucja młodzieży współczesnej, „Ruch Pedagogiczny” 1930, nr 1.

Friedländer M., Rodzice a wychowanie, „Przegląd Społeczny” 1929, nr III.

Friedländer M., Romain Rolland a wychowanie, "Ruch Pedagogiczny” 1926, nr 8.

Friedländer M., Sens nauczania języków obcych w szkole. Wychowanie państwowe a języki obce. Przyczynek do zagadnienia doboru lektury, „Neofilolog” 1931, z. 4-5.

Friedländer M., Szkoła i młodzież wobec literatury, "Oświata i Wychowanie” 1930, nr 1.

Friedländer M., Szkota Rabindranatha Tagorego w Szantiniketan, „Ruch Pedagogiczny” 1926, nr 3.

Friedländer M., Uspołecznianie się dziecka w wieku przedszkolnym, „Życie Dziecka” 1933, nr 7 i nr 8.

Friedländer M., Walka o lekturę dla młodzieży, „Neofilolog” 1931, nr 3.

Friedländer M., Wychowanie, szkoła i pokój, „Ruch Pedagogiczny” 1927, nr 8 i nr 9.

Friedländer M., Wyktady radiowe z dziedziny pedagogiki Min. W. R. i O. P, „Ruch Pedagogiczny" 1927, nr 5 .

Friedländer M., Zadania opieki społecznej nad młodzieża, „Przegląd Społeczny” 1928, nr IX.

Friedländer M., Zagadnienia ptciowe w wychowaniu młodzieży, „Przegląd Społeczny" 1929, nr VI, VII, VIII, IX, X.

Friedländer M., Zakres „Nauki o kulturze” w nauczaniu języka niemieckiego, „Neofilolog” 1930, z. 3 .

Friedländer M., Zmiany duchowe młodzieży w wieku przełomowym, „Przegląd Społeczny” 1929, nr I i nr II.

Friedländer M., Życie duchowe młodzieży żeńskiej, „Ruch Pedagogiczny” 1925, nr 9-10.

Friedländer M., Znaczenie środowiska w wychowaniu, "Ruch Pedagogiczny” 1928, nr 9, s. 257-268 i nr 10.

Goethe J.W., Faust, przypisami opatrzył M. Friedländer, Lwów 1938.

H. N., Kurs metodyczny języków obcych we Lwowie, „Neofilolog” 1932, z. 2.

Hulewicz J., Michat Friedländer (1894-1942/3?), „Przegląd Historyczno-Oświatowy” 1949, nr 4 (zeszyt szczotkowy).

Hulewicz, Friedländer Michał, Polski Słownik Biograficzny, t. 7, Kraków 1958. 
Kollegjum wykładów naukowych, „Naprzód” 1932, nr 34.

Münchhausens Reisen Und Abenteuer, opracował M. Friedlander, Kraków 1939.

VII Sprawozdanie Dyrekcji Prywatnego Gimnazjum Koedukacyjnego, Szkoły Powszechnej i Męskiej Szkoły Rzemiost Żydowskiego Towarzystwa Szkoły Ludowej i Średniej w Krakowie za rok szk. 1934-35, Kraków 1935.

Sternbach H., Michat Friedländer: Lektura obcojęzyczna w szkole średniej. Szkic metodyczny. Część I. Rozważania ogólne. Metodyczna Biblioteka Neofilologiczna. Nr 1. Skład główny: Księgarnia Gebethner i Wolff. Kraków 1935, „Neofilolog” 1935, nr 4.

Storm T., Immensee. Wstępem i przypisami opatrzył Michał Friedländer, Lwów-Warszawa 1935. 